\title{
Tunnelling hazard in the diversion tunnel of Sengulam Augmentation Scheme, Idukki district, Kerala
}

\author{
KR Praveen, CS Vishnu and C Thanavelu \\ Geological Survey of India, \\ Thiruvananthapuram, India \\ geopraveen@gmail.com
}

\begin{abstract}
A free flow diversion tunnel is designed as a part of Sengulam Augmentation Scheme envisaged to increase the storage in an already existing reservoir at Sengulam, in turn power generation by transferring water available at Kallar River Basin. The tunnel is driven through gneissic bedrock with granite, alkali syenite and pegmatite intrusives. Completely weathered zones along selective intrusive bodies and four sets of shear zones are the geological adversities present in the rock mass that caused multitypes of failure during driving of the tunnel. The most susceptibile constituent mineral assemblages of fayalite bearing syenite and pegmatite in conjunction with syn/post intrusive shearing with influx of hydrothermal solution could be the reason for the abnormal depth of weathering. Caving, squeezing and flowing types of failure occurred in the tunnel reaches with thoroughly weathered rock. Whereas planar and wedge failures taken place in the sheared, fractured and closely jointed rock mass with mylonite or gouge filled smooth planar joints. The failure mechanisms, method of driving and support interventions are described in this paper.
\end{abstract}

Keywords-Sengulam Augmentation Scheme; diversion tunnel; causative factors; failure mechanisms; support intervention

\section{INTRODUCTION}

Sengulam Augmentation Scheme (SAS) envisages transfer of water from Western Kallar River Basin to the existing Sengulam Reservoir by constructing a $10 \mathrm{~m}$ high concrete gravity weir and a $6.8 \mathrm{~km}$ long, $3.50 \mathrm{~m}$ diameter free flow diversion tunnel. The weir site is located $15 \mathrm{~m}$ upstream of the bridge over Kallar River on NH-49 (Fig. 1). Commencing in the year 2010, the project is under advanced stage of construction. Driving of the tunnel is being done by drilling and blasting method with six faces, one each from inlet and exit and two each from two adits (Fig. 2). The tunnel has been driven for about $4090 \mathrm{~m}$. The authors were associated with the $3 \mathrm{D}$ geological logging of about $530 \mathrm{~m}$ reach of the tunnel and collected data for characterisation of the rock mass media.

\section{Regional Geological Mileu}

Located in the Munnar plateau, the project area forms part of the Southern Granulite Terrain occupied by rocks of Peninsular Gneissic Complex (PGC), Charnockite Group and Migmatitic Complex. PGC is represented by well foliated and regionally folded granite gneiss. The constituent of the Charnockite Group is charnockite and pyroxenite. In general, massive variety of charnockite occupies the ridges and gneissic variety is exposed mainly in the valleys of the ridge and valley topography present in the vicinity of the project. Rocks of Migmatite Complex comprise biotite gneiss and hornblende biotite gneiss.

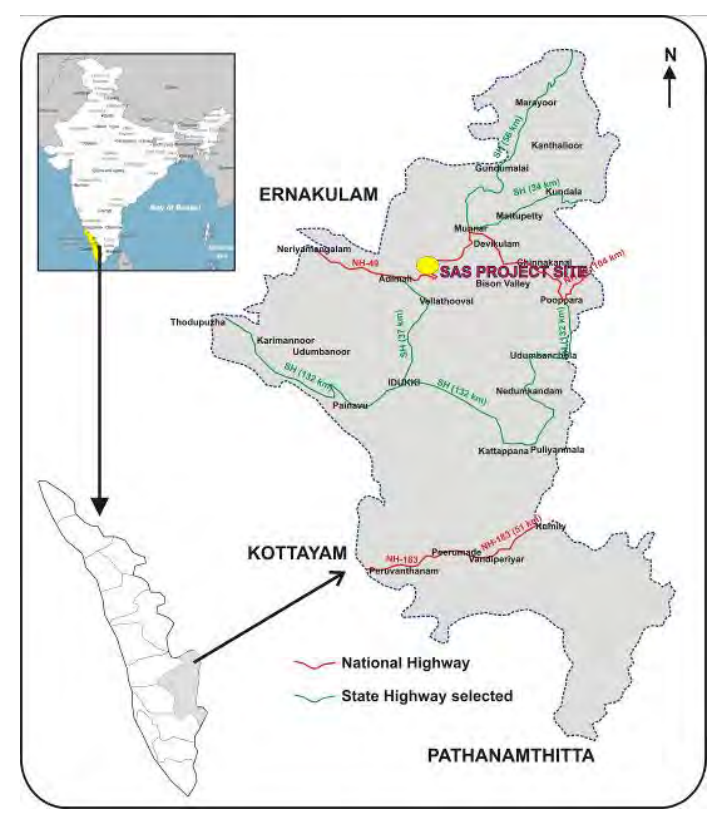

Fig. 1. Location map of SAS

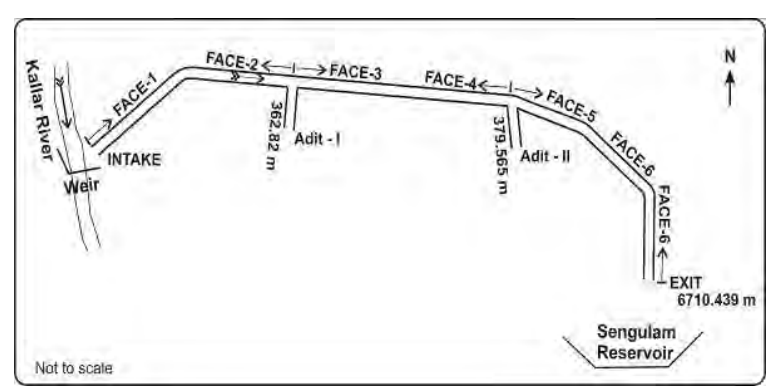

Fig. 2. Schematic diagram of diversion tunnel of SAS 
The oldest lithounits (Supracrustals) are represented by pyroxene granulite / amphibolite and magnetite quartzite occurring as linear bands and enclaves parallel to the foliation within the gneisses and charnockite. Granite emplacement is predominantly present around Munnar, Devikulam and some places along the eastern part of the plateau. Felsic and basic rocks occurring as intrusives in the bed rock is the conspicuous characteristic of the project environs. The felsic variety is represented by pegmatite, syenite and quartz, whereas dolerite dyke is the predominant basic variety. Occurrence of nepheline syenite and carbonatite bodies is also reported in the area $[1,2]$. The intrusion of syenite and carbonatite bodies is correlated with $\mathrm{NE}$ - SW trending rift magmatism [1]. Five sets of fracture tectonic features are deciphered in the terrain with trends WNW - ESE, NW - SE, NNW - SSE, NNE - SSW and ENE - WSW.

\section{SiTE GEOLOGY}

3D geological mapping of the tunnel indicated that the tunnel is driven through the country rock constituted by fissile hornblende biotite gneiss, granite gneiss and charnockite. Granite, alkali syenite and pegmatites are occurring as intrusive bodies and veins within the country rock.

Olivine bearing alkali syenite (larvikitic) and pegmatite are found to occur as a multiple intrusion as observed in the weathered zone in Face - 4 (Fig. 3) of the diversion tunnel. These intrusive veins and bodies are in general trending in NW - SE direction parallel to Ottappalam - Kuttampuzha fault and disposed askew to the tunnel alignment. Pink and yellowish green minerals are dominantly present with conspicuous pockets and veins of epidote in the intrusive rocks particularly that are deeply weathered. The predominant discontinuities present in the rock mass include foliation, five prominent and persistent joint sets and four sets of shears.

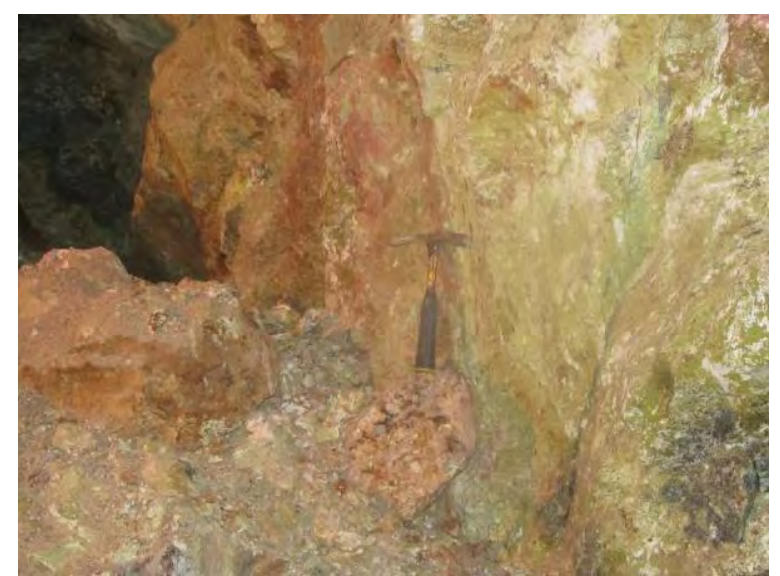

Fig. 3. Weathered olivine bearing alkali syenite and pinkish pegmatite with sharp contact

\section{A. Foliation}

Strike varies from $\mathrm{N} 30^{\circ} \mathrm{W}-\mathrm{S} 30^{\circ} \mathrm{E}$ to $\mathrm{N} 60^{\circ} \mathrm{W}-\mathrm{S} 60^{\circ} \mathrm{E}$ and $\operatorname{dip} 60^{\circ}$ to $70^{\circ}$ towards NE. The foliation is very well developed, crenulated and very closely spaced. Sharp swerves in foliation owing to folding are commonly noticed in the tunnel rock mass.

\section{B. Joints}

1. Strike $\mathrm{N} 35^{\circ}$ to $50^{\circ} \mathrm{W}-\mathrm{S} 35^{\circ}$ to $50^{\circ} \mathrm{E}$, dip $70^{\circ}$ to $82^{\circ}$ towards NE. Foliation joint

2. Strike $\mathrm{N} 20^{\circ}$ to $50^{\circ} \mathrm{E}-\mathrm{S} 20^{\circ}$ to $50^{\circ} \mathrm{W}$, dip $30^{\circ}$ to $60^{\circ}$ towards SE. Closely to moderately spaced.

3. Strike $\mathrm{N} 35^{\circ}$ to $60^{\circ} \mathrm{W}-\mathrm{S} 35^{\circ}$ to $60^{\circ} \mathrm{E}$, dip $50^{\circ}$ to $70^{\circ}$ towards SW. Moderately spaced

4. Strike $\mathrm{N} 55^{\circ}$ to $70^{\circ} \mathrm{E}-\mathrm{S} 55^{\circ}$ to $70^{\circ} \mathrm{W}$, dip $40^{\circ}$ to $55^{\circ}$ towards NW (moderately spaced)

5. Strike $\mathrm{N} 10^{\circ}$ to $15^{\circ} \mathrm{W}-\mathrm{S} 10^{\circ}$ to $15^{\circ} \mathrm{E}$, dip $40^{\circ}$ to $75^{\circ}$ towards WSW (widely spaced)

\section{Shear zones}

1. Strike $\mathrm{N} 70^{\circ} \mathrm{E}-\mathrm{S} 70^{\circ} \mathrm{W}$, dip $65^{\circ}$ towards $\mathrm{N} 20^{\circ} \mathrm{W}$. Slickensides plunging oblique towards downstream.

2. Strike $\mathrm{N} 70^{\circ} \mathrm{W}-\mathrm{S} 70^{\circ} \mathrm{E}$, dip $80^{\circ}$ towards $\mathrm{S} 20^{\circ} \mathrm{W}$.

3. Strike $\mathrm{N} 15^{\circ} \mathrm{E}-\mathrm{S} 15^{\circ} \mathrm{W}$, dip $55^{\circ}$ towards $\mathrm{N} 75^{\circ} \mathrm{W}$

4. Strike $\mathrm{N} 60^{\circ} \mathrm{W}-\mathrm{S} 60^{\circ} \mathrm{E}$, dip $55^{\circ}$ towards $\mathrm{S} 30^{\circ} \mathrm{W}$

Thin zones with width less than $10 \mathrm{~cm}$ and gouge or mylonite filled joints are connoted as shear joints.

\section{Weathered Zones}

1. $\mathrm{N} 45^{\circ} \mathrm{W}-\mathrm{S} 45^{\circ} \mathrm{E}$, dip $50^{\circ}$ towards $\mathrm{SW}$ along multiple intrusive olivine syenite and pegmatite. The exposed width in the tunnel is about $90 \mathrm{~m}$ and expected to continue at least for another $100 \mathrm{~m}$.

2. $\mathrm{N} 70^{\circ} \mathrm{E}-\mathrm{S} 70^{\circ} \mathrm{W}$, dip $65^{\circ}$ towards $\mathrm{S} 20^{\circ} \mathrm{E}$. Weathered shear zone with thickness 20 to $30 \mathrm{~cm}$.

3. Strike $\mathrm{N} 10^{\circ} \mathrm{E}-\mathrm{S} 10^{\circ} \mathrm{W}$, dip $55^{\circ}$ towards $\mathrm{N} 80^{\circ} \mathrm{W}$. Weathering along sheared pegmatoidal granite vein with width of about $4 \mathrm{~m}$.

\section{ROCK MASS CHARACTERISATION}

The general rock mass of the logged and assessed reach of the diversion tunnel is fresh, blocky to seamy with welldeveloped foliation. Fissile nature of rock mass with very closely spaced and crenulated foliation indicate that the rock mass has undergone multi-episodes of flexure deformation resulting in development of many sets of fracture fabrics. Intense folding, pink permeation and development of fissility are predominantly noticed in the reach from $4451 \mathrm{~m}$ to $4471 \mathrm{~m}$ in Face 5. In general, the excavated section of the tunnel except in the failed reaches is observed to be smooth or slightly serrated with fair rock mass.

The rock mass is thoroughly weathered in the reach from Ch.4004 $\mathrm{m}$ to $4095 \mathrm{~m}$. The weathering is to the extent that the rock has become clayey sand even at about $135 \mathrm{~m}$ below the ground level (Fig. 3). The weathered rock material is very fine to coarse grained, soft, friable and dominated either with yellowish green or pinkish colours. The rock is subjected to shearing evidenced by presence of relict angular fragments and fractures in the epidote rich matrix. 


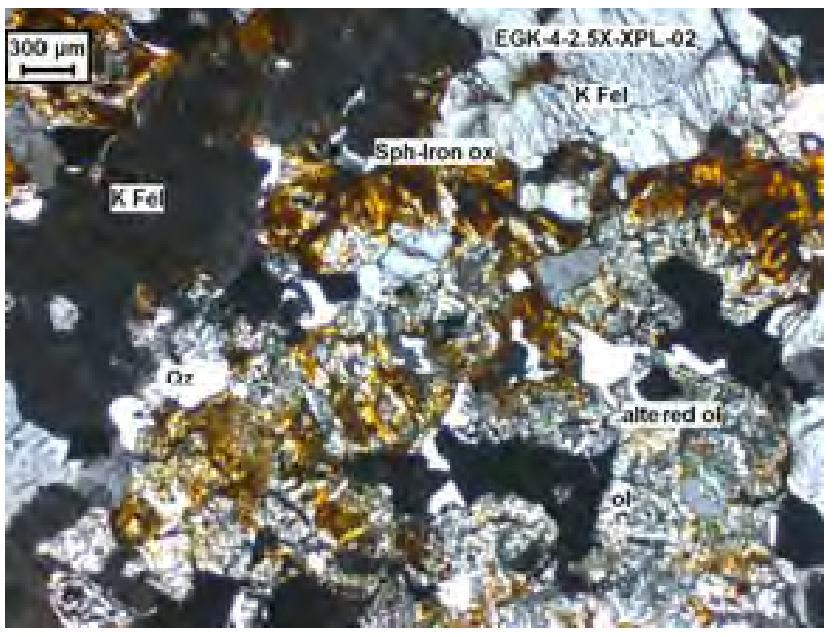

Fig. 4 : Photomicrograph of weathered olivine bearing alkali syenite

Kaolinised and sericitized K-feldspars, epidote, zoisite and altered fayalite are occurring as framework minerals in the breccia. The matrix of the breccia is fine, variegated with yellow, green, yellowish brown and also comprises aggregates of epidote, altered product of K-feldspars viz. sericite and kaolin. Opaques mainly of iron oxides, sphene and allanite are the other minor minerals identified in the matrix (Fig. 4). The yellowish epidote in matrix is found to altering to brownish material probably oxy-allanite.

Based on the petrographic studies, it is inferred that the original rock could have been fayalite bearing alkali syenite (larvikitic). The protolith is subjected to shearing resulting to brecciation and influx of hydrothermal solutions rich in epidote, sphene and iron oxide. Presence of epidote occurring as vein could also indicate simultaneous metasomatism. Shearing facilitated infiltration and migration of water and the least resistant mineral assemblages of intrusive rocks caused extension of weathering to deeper level.

\section{TyPes ANd CAUSES of FAILURES}

Caving, squeezing and flowing, planar and wedge types of failure have been identified in the tunnel. The discussion on the causes and mechanism of individual failures are dealt hereunder.

\section{A. Caving, squeezing and flowing failures}

Caving type of failure has occurred from Ch. $4004 \mathrm{~m}$ to $4095 \mathrm{~m}(91 \mathrm{~m})$ in Face 4 . The extent of caving varies from about $1.5 \mathrm{~m}$ to $3 \mathrm{~m}$ beyond the designed profile. Presence of completely weathered zone is assessed to be the cause for the failures. Bending of steel ribs and development of cracks in concrete lining with shifting or converging towards the opening are observed particularly on the right wall of the tunnel between chainage $4002 \mathrm{~m}$ and $4006 \mathrm{~m}$.

Squeezing of the weathered material due to high stress could be the reason for development of cracks and the associated movement (Fig. 5). Flowing type of failure is met at about chainage $4002 \mathrm{~m}$ (Fig. 6). Completely weathered, stressed rock mass saturated with percolated and accumulated water from the surface is assessed to be the cause for the flowing failure.

\section{B. Planar failures}

Failure and collapse of sheared rock mass resulting in formation of linear cavities had occurred along the shear zones manifesting close fracturing, brecciation and development of soft mylonite or gouge. Four sets of shear zones of thickness varying from $1 \mathrm{~m}$ to $4 \mathrm{~m}$ have been met in the tunnel causing failures in Faces 5 and 6 from chainage $4411.3 \mathrm{~m}$ to $5260.4 \mathrm{~m}$. These shear zones are found to be parallel to WNW-ESE trending Periyar, ENE-WSW trending Mattupetty and N-S trending Erattayar shear zones and NW-SE trending Ottappalam-Kuttampuzha fault. The intrusion of alkali syenite is found to be along the parallel feature of the Ottappalam Kuttampuzha fault.

The collapses were instantaneous with driving of the tunnel. Loosening and falling of rock blocks continued till the erection of the supports in these reaches. The failed mass from shear zones comprises of considerable quantity of powdery materials mixed with irregular shaped small pieces. Moderately big tubular, rectangular and cuboidal rock blocks were predominant in the mass that have failed from the fractured and closely jointed zones with multiple shear joints.

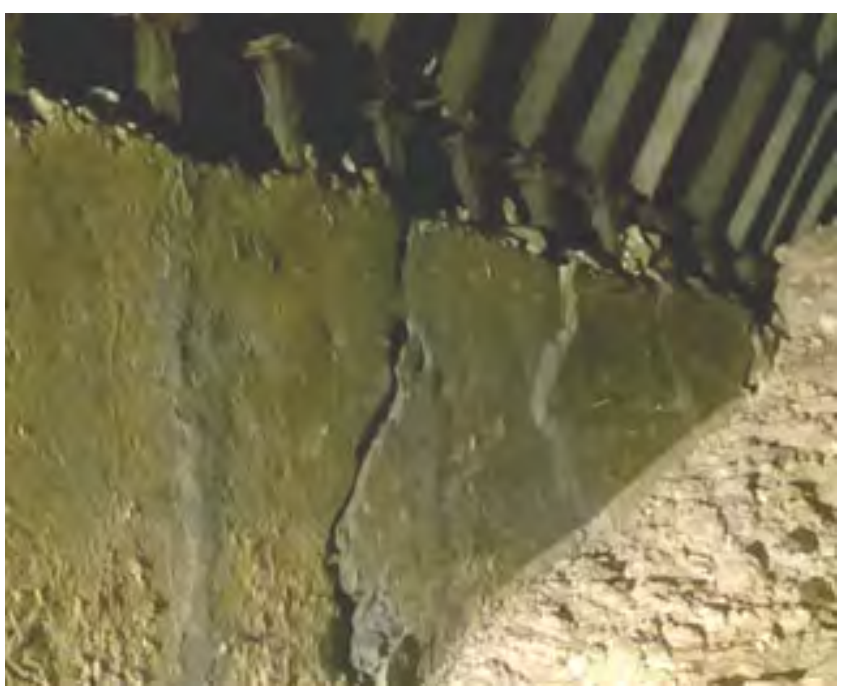

Fig. 5. Depicts bending of steel ribs and development of cracks in concrete lining in Face 4.

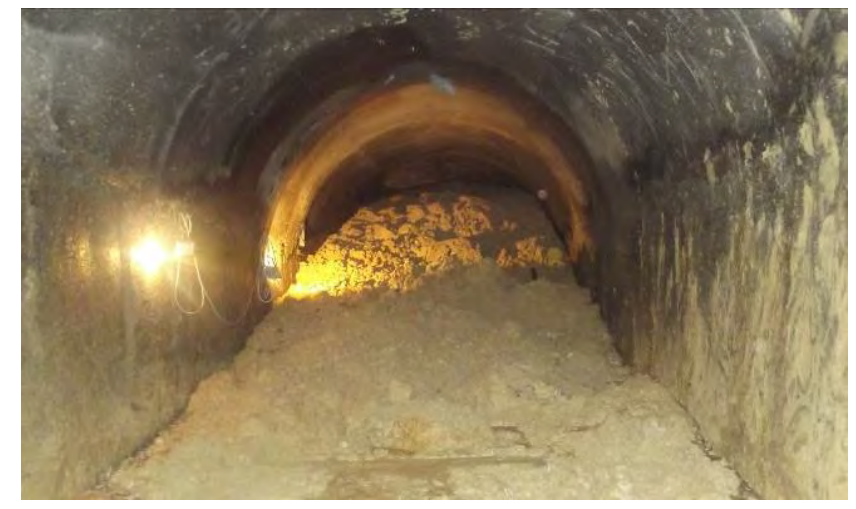

Fig. 6. Flowing condition met in Face 4 
Failures were initiated by shear movement of rock blocks present between two parallel mylonite or gouge filled joints leaving linear cavities. Four faces of the failed blocks are bounded by smooth planar strained/weathered joints and the other two faces by irregular and wavy fractures. The irregular planes could have been resulted due to snapping by tension [3].

\section{Wedge failures}

Failures by over breaks up to $3.5 \mathrm{~m}$ have also been occurred due to dislodgement of rock wedge at the intersection of weak, sheared / weathered zones and shear joints or only shear joints mainly in the reach from $5150.4 \mathrm{~m}$ to $5260.4 \mathrm{~m}$ in Face 6 (Fig. 7, 8, 9). The failed rock mass comprised mainly rhomboidal and cuboidal blocks of varying sizes limited by smooth, strained and weathered planes. Loosening of blocks could have been initiated by shear movement along two filled joints due to reduction in inter block friction aided by the presence of water charged gouge fillings. The causative features are parallel to the Periyar and Mattupetty shear zones, both disposed at about $30^{\circ}$ askew to the tunnel alignment. The third low dipping smooth planar joints are acted as limiting plane.

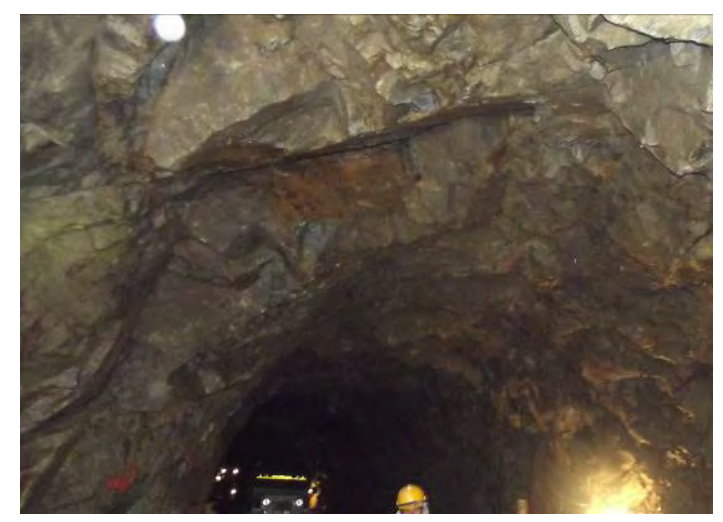

Fig. 7. Over break due to failure of wedges in Face -6

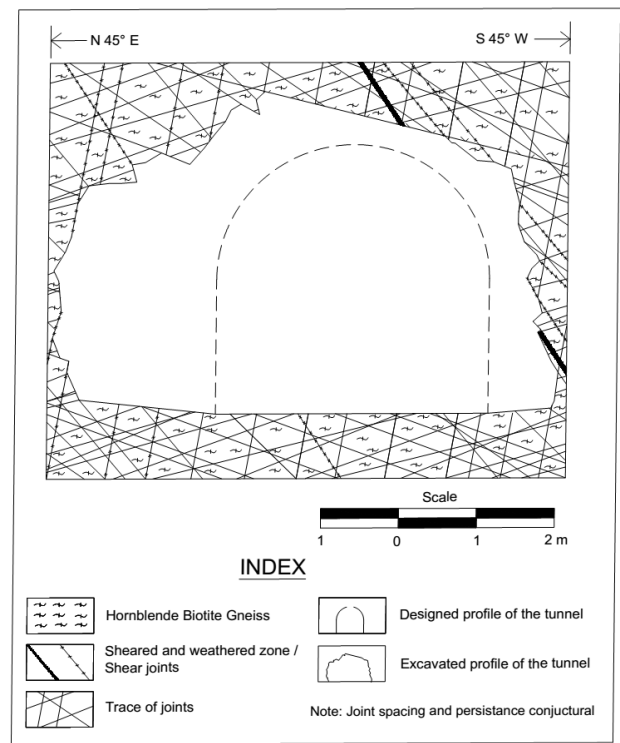

Fig. 8. Geological cross section of wedge failure at Ch. $5150.84 \mathrm{~m}$ in Face-6

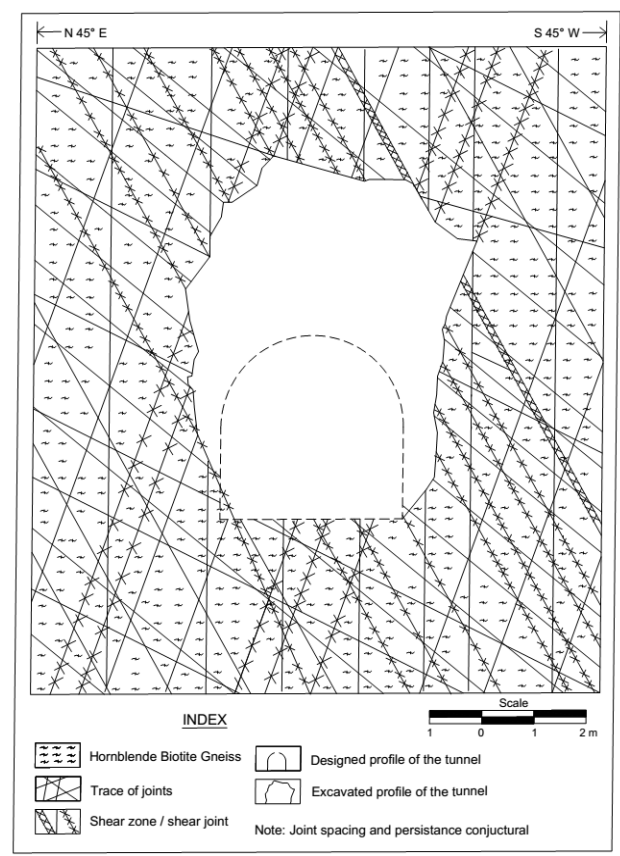

Fig. 9. Geological cross section of the failed reach at Ch. $5211.44 \mathrm{~m}$ in Face-6

\section{RECOMMENDATIONS}

Suitable method of tunnelling to negotiate the flowing zone met in Face 4 and long term support interventions for the reaches of failures have been recommended.

\section{A. Method of Tunnelling}

In order to negotiate the reaches with squeezing and flowing conditions, it is suggested to carry out measures such as draining of flown muck by inserting horizontal perforated pipes, grouting of the flown muck, excavation of the flown muck up to the original face, pre-grouting, provision of pipe roofing or fore poling in the crown and horizontal drain pipes on the driving face. Further driving of the tunnel may be resumed by adopting heading and benching or multiple drifting methods with simultaneous rib support and concrete lining suitably.

\section{B. Support Interventions}

The reaches with caving type of failures in Face 4 is recommended to be supported with steel ribs spaced at $0.5 \mathrm{~m}$ with suitably spaced props touching the excavated profile, provision of concrete sleeper between steel ribs, rubble packing and grouting. Blocking concrete embedding the steel ribs is recommended instead of back packing and grouting. As recommended, tunnelling was furthered by simultaneous support till met with squeezing and flowing hazard. Provision of steel rib support has also been recommended for the reaches of heavy over breaks with continuing loose fall that has been driven through sheared rock mass. Classified the rock mass of the other reaches and worked out support system as per updated ' $Q$ ' system [4]. The reach wise details on ' $Q$ ' value and support system recommended are given in the Table I.

As there is no design requirement of maintaining the section of the free flow tunnel, recommended support interventions that will hug the excavated profile. 
Table I. Support Measures Based On 'Q’ From Reaches 4767.3 M To $5260.4 \mathrm{M}$

\begin{tabular}{|c|c|c|c|c|}
\hline $\begin{array}{l}\text { SI. } \\
\text { No. }\end{array}$ & $\begin{array}{l}\text { Chainages } \\
\text { (m) }\end{array}$ & $\begin{array}{c}\mathbf{Q} \\
\text { value }\end{array}$ & $\begin{array}{c}\text { Nature of Rock } \\
\text { Mass }\end{array}$ & $\begin{array}{l}\text { Support } \\
\text { Measures }\end{array}$ \\
\hline 1 & $\begin{array}{ll}4767.3 \quad- \\
5150.4\end{array}$ & 5.3 & Blocky & No Support \\
\hline 2 & $\begin{array}{l}5150.4 \\
5159.4\end{array}$ & 2 & $\begin{array}{l}\text { Blocky with minor / } \\
\text { moderate over break } \\
\text { at the intersection of } \\
\text { slickensided and } \\
\text { smooth planar joints. }\end{array}$ & $\begin{array}{lr}\text { Systematic } & \text { rock } \\
\text { bolting and } & \text { plain } \\
\text { shotcreting } & \text { of } \\
\text { about } 10 \mathrm{~cm} . & \end{array}$ \\
\hline 3 & $\begin{array}{l}5159.4 \\
5216.4\end{array}$ & $\begin{array}{l}0.13 \text { to } \\
0.25\end{array}$ & $\begin{array}{l}\text { Seamy and sheared } \\
\text { with heavy to very } \\
\text { heavy over break due } \\
\text { to intersection of } \\
\text { sheared and } \\
\text { weathered zones } \\
\text { with shear joints. }\end{array}$ & $\begin{array}{l}\text { Rock bolting and } \\
\text { Rebar Reinforced } \\
\text { Shotcreting of } \\
\text { about } 30 \mathrm{~cm} \text {. }\end{array}$ \\
\hline 4 & $\begin{array}{l}5216.4 \\
5256.4\end{array}$ & 8 & Blocky & No Support \\
\hline 5 & $\begin{array}{l}5256.4 \\
5260.4\end{array}$ & 0.5 & Fractured / sheared & $\begin{array}{l}\text { Rock bolting and } \\
\text { mesh reinforced } \\
\text { shotcreting of } \\
\text { about } 10 \mathrm{~cm} .\end{array}$ \\
\hline
\end{tabular}

\section{CONCLUSIONS}

The tunnelling hazard in the diversion tunnel of Sengulam Augmentation Scheme occurred in the form of caving, squeezing, flowing, planar and wedge failures. Presence of completely weathered zone, high accumulated stress and saturation of the stressed rock mass with percolated water is assessed to be the causes for caving, squeezing and flowing failures respectively. The alteration of fayalite bearing alkali syenite and pegmatite intrusives in conjunction with syn/post shearing with influx of hydrothermal solution is inferred to be the cause of deep weathering to an abnormal depth. The presence of four sets of shear zones and the shear movement of rock blocks present between two parallel gouge filled joints leaving linear cavities may be responsible for planar failures while dislodgement of rock wedge at the intersection of weak sheared/weathered zones and shear joints resulted in wedge failures. Classified the tunnelling media based on parametric assessment of the rock mass and discontinuity fabrics and recommended support interventions, besides measures and method of tunnelling to negotiate the completely weathered high stress zone charged with water.

\section{ACKNOWLEDGEMENTS}

The authors are thankful to the Director General, GSI, Kolkata for according permission to publish this paper. They would like to express their sincere gratitude to the Additional Director General, Southern Region, Hyderabad and the Deputy Director General, Kerala State Unit of Geological Survey of India for the support rendered. The authors would like to place on record their heartfelt thanks to Dr. G. Suresh, Director, Petrology Division, GSI, SR for the petrographic analysis.

\section{REFERENCES}

[1] C. Leelanandam, K. Burke, L.D. Ashwal and S.J. Webb, "Proterozoic mountain building in Peninsular India: an analysis based primarily on alkaline rock distribution", Geol. Mag., v.143(2), pp.195-212, 2006.

[2] M. Santosh, K. Yokoyama, S. Biju- Sekhar and J.J.W. Rogers, "Multiple tectonothermal events in the granulite blocks of southern India revealed from EPMA dating: implications on the history of supercontinents", Gondwana Res., v.6, pp.29-63, 2003.

[3] C. Thanavelu, G. Rajagopalan and S. Chandrasekaran. "Causes and Mechanism of failures in Vazhikadavu Tunnel, Idukki District, Kerala, India”, Proc. Sixth International R \& D Conference, Lucknow, India, pp. 391-401, 2007.

[4] E. Grimstad and N. Barton, "Updating the Q-system for NMT". Proc. Int. Symp. On Sprayed Concrete - Modern Use of Wet Mix Sprayed Concrete for Underground Support”, Fagernes, Oslo : Norwegian Concrete Association, pp. 46-66, 1993. 